\title{
Feeding the Building Plumbing Microbiome: The Importance of Synthetic Polymeric Materials for Biofilm Formation and Management
}

\author{
Lisa Neu ${ }^{1,2}$ and Frederik Hammes ${ }^{1, *}$ \\ 1 Department of Environmental Microbiology, Eawag: Swiss Federal Institute for Aquatic Science and \\ Technology, 8600 Dübendorf, Switzerland; lisa.neu@eawag.ch \\ 2 Department of Environmental Systems Science, Institute of Biogeochemistry and Pollutant Dynamics, \\ ETH Zürich, 8092 Zürich, Switzerland \\ * Correspondence: frederik.hammes@eawag.ch; Tel.: +41-58-765-5372
}

Received: 19 May 2020; Accepted: 15 June 2020; Published: 22 June 2020

\begin{abstract}
The environmental conditions in building plumbing systems differ considerably from the larger distribution system and, as a consequence, uncontrolled changes in the drinking water microbiome through selective growth can occur. In this regard, synthetic polymeric plumbing materials are of particular relevance, since they leach assimilable organic carbon that can be utilized for bacterial growth. Here, we discuss the complexity of building plumbing in relation to microbial ecology, especially in the context of low-quality synthetic polymeric materials (i.e., plastics) and highlight the major knowledge gaps in the field. We furthermore show how knowledge on the interaction between material properties (e.g., carbon migration) and microbiology (e.g., growth rate) allows for the quantification of initial biofilm development in buildings. Hence, research towards a comprehensive understanding of these processes and interactions will enable the implementation of knowledge-based management strategies. We argue that the exclusive use of high-quality materials in new building plumbing systems poses a straightforward strategy towards managing the building plumbing microbiome. This can be achieved through comprehensive material testing and knowledge sharing between all stakeholders including architects, planners, plumbers, material producers, home owners, and scientists.
\end{abstract}

Keywords: building plumbing systems; synthetic polymeric material; microbiome; management

\section{Drinking Water Microbiology from Source to Tap}

\subsection{Bacteria Are Omnipresent in Drinking Water Treatment and Distribution Systems}

Bacteria inhabit nearly every part of drinking water systems [1]. Complex microbial communities, comprising thousands of unique taxa, are found at various concentrations $\left(10^{3}-10^{6}\right.$ cells $\left./ \mathrm{mL}\right)$ [2-4] from the source water [5-7], through different treatment stages [8-10], through the drinking water distribution system (DWDS) [11-13] and building plumbing system right up to the tap [14-16] (Figure 1). Along the DWDS (i.e., from post-treatment until the property line), the majority of bacteria $(\sim 98 \%)$ is present in the form of biofilms and/or attached to particles, while only $\sim 2 \%$ are present as planktonic cells in the water phase [17]. Here, typical pipe surface biofilm concentrations range between $10^{5}-10^{7}$ cells $/ \mathrm{cm}^{2}[18,19]$. The DWDS of the City of Zurich (Switzerland) comprises $1100 \mathrm{~km}$ of main and distribution pipes [20]. Calculating with an average inner pipe diameter of $100 \mathrm{~mm}$, this translates to $3 \times 10^{5} \mathrm{~m}^{2}$ pipe surface and $9 \times 10^{3} \mathrm{~m}^{3}$ of water. 


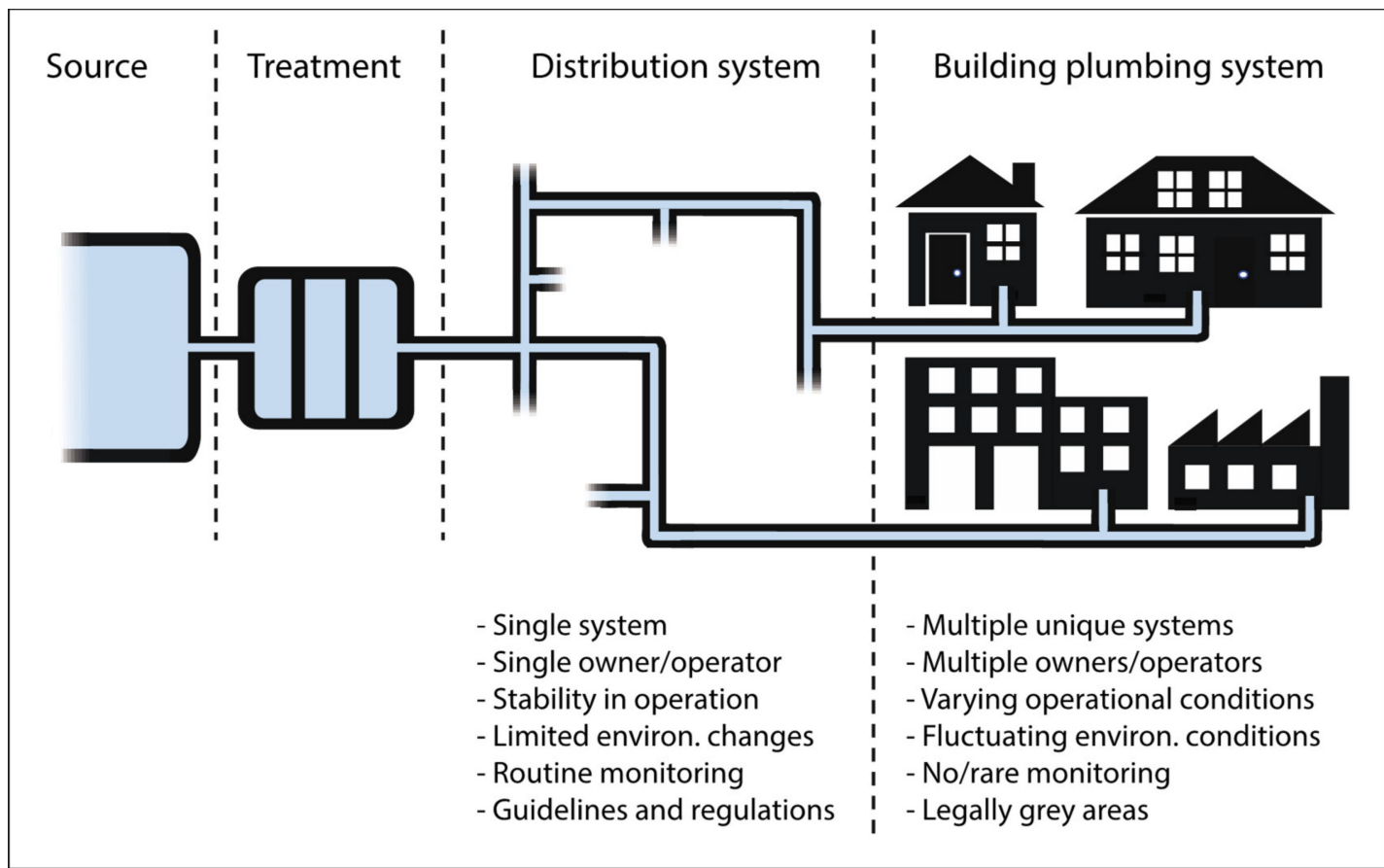

Figure 1. Drinking water from source to tap, highlighting key differences between the main distribution system and building plumbing systems.

Considering a planktonic bacterial concentration of up to $\sim 1 \times 10^{5}$ cells $/ \mathrm{mL}$ after treatment [2] and a biofilm-to-water distribution of 98:2 (above), this means an estimated total of $4 \times 10^{16}$ attached cells and $0.1 \times 10^{16}$ planktonic cells for the entire DWDS; spectacular numbers indeed.

\subsection{The Microbiology of DWDS Is Studied, Monitored, and Regulated}

The microbiology of DWDS has been studied intensively (e.g., $[17,21])$ and is routinely monitored by utilities, following defined regulations. Here, several aspects allow for a comparatively controlled, and thus manageable, environment. First, a DWDS is often operated by a single "owner" (i.e., water utility), which allows for structured planning, operation, management, and monitoring. Second, legal guidelines and regulations are in place and areas of responsibilities are defined, e.g., which pipe materials to use or which water quality variables to monitor (e.g., EU guideline: DWD 98/83/EC [22]; USA (EPA) Safe Drinking Water Act [23]). Third, DWDS have relatively limited fluctuations in operating conditions. For example, the water in DWDS mains is essentially flowing continuously, resulting in (comparatively) limited changes in flow dynamics and water age at any given point in the system.

\subsection{The Microbiology of DWDS Is Prone to (Environmental) Temporal and Spatial Changes}

An ideal DWDS is microbiologically stable, meaning the water quality does not change during distribution (e.g., [24]). However, and despite comparatively limited fluctuations, temporal and spatial changes have still been documented. This includes short-term changes in planktonic cell concentrations, which can be attributed to fluctuations in flow velocity, following trends in water consumption throughout the day [25], and seasonal changes in both cell concentrations [26] and microbiome composition [27], presumable linked to changes in environmental conditions. In similar vein, spatial variations in bacterial concentration and composition resulted for example from increased water age and the depletion of disinfectant residuals throughout the DWDS $[28,29]$. 


\subsection{Changes in Microbiological Quality Are Problematic}

From an ecological perspective, understanding the link between changes in environmental conditions and changes in the drinking water microbiome is interesting. Unfortunately, changes such as these may also have profoundly adverse consequences for the drinking water quality. For example, the increased detection of Mycobacterium avium in a DWDS was linked to water age and the depletion of chlorine during distribution [30], and seasonal temperature changes within several DWDS were correlated with the growth of coliforms [31]. The most dramatic, least understood, and usually uncontrolled changes in environmental conditions occur when water from the DWDS enters building plumbing systems (also referred to as "premise(s) plumbing" [32,33] or "domestic plumbing" [34,35]). As discussed below, the environmental conditions between and within building plumbing systems change dramatically relative to the DWDS and relative to each other (Figure 1), and consequently so does the microbiology.

The purpose of this review was (1) to emphasize the complexity of building plumbing in relation to microbial ecology, especially in the context of low-quality synthetic polymeric materials (i.e., plastics) and (2) to highlight major knowledge gaps in the field. This should ultimately (3) highlight the need for more research on the fundamental aspects of biofilm growth in building plumbing systems, (4) allowing for both a better understanding and better options of proactive management of the microbiology in the built environment.

\section{Building Plumbing Systems Change the Microbiology}

\subsection{The Microbiological Black Box Between the Water Meter and the Tap}

A number of studies on building plumbing microbiology emerged during the past decade, for example investigating the impact of temperature on community composition [15], refining adequate building sampling strategies [36], monitoring biofilm formation in a new building [16], or evaluating the impact of stagnation on microbiome assemblages [14]. Despite this increase in knowledge, building plumbing microbiology still remains considerably less studied than DWDS microbiology, insufficiently monitored, and consequently, poorly understood. The two main reasons for this are (1) the severe challenges in sampling and monitoring buildings due to legal restrictions and (2) the constructional complexity of building plumbing systems.

Legal guidelines in most developed countries cover drinking water safety until the point of use (e.g., Drinking Water Directive, EU [22]; TrinkwV, Germany [37]). While this in theory also renders water utilities responsible for safe water within both private and public buildings, additional interpretations of the legislation allow for the transfer of legal obligations to building owners (e.g., AVBWasserV, Germany [38]). The consequence is that most buildings, and particularly private homes, are not controlled from a microbiological perspective on a regular basis, if at all.

Apart from legal aspects, additional challenges stem from the complexity of building plumbing systems. Not only are there thousands of unique buildings connected to each DWDS (e.g., $>20,000$ single-family houses in the City of Zurich (data 2010 [39])), but each building plumbing system also consists of multiple, different sub-units such as boilers, rising mains, and ring mains. In addition, each system typically has warm and cold water outlets (Figure 2), with hoses, taps, and various connected home appliances (e.g., a washing machine), all of which will potentially create unique and very different environments. From a microbiological point of view, bacteria that enter a building plumbing system from the DWDS experience an immediate and considerable change in environmental conditions, and it is common knowledge that a change in environmental conditions will often result in a change in bacterial numbers [40], viability [41], activity [42], and composition [43]. 


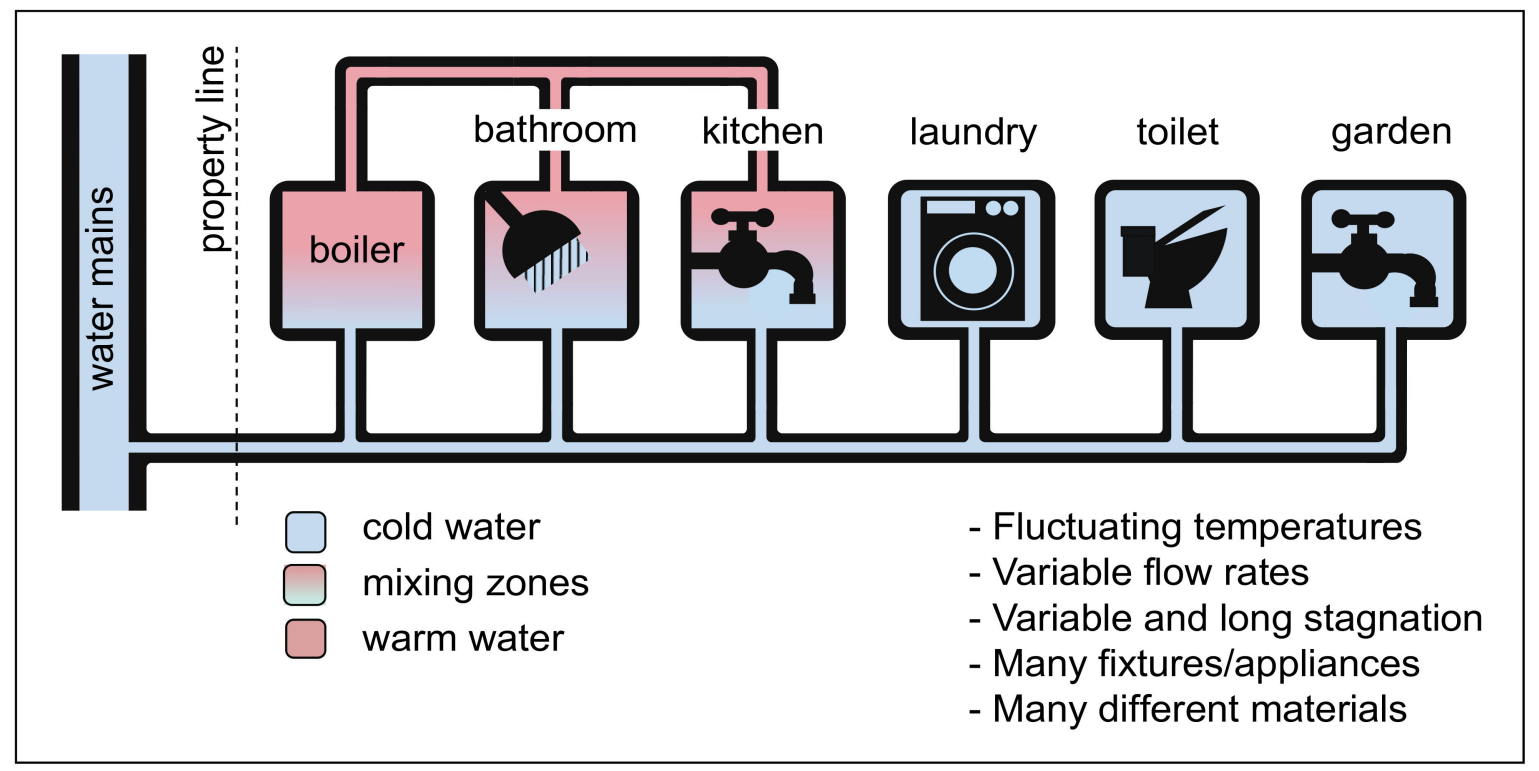

Figure 2. The complexity of building plumbing systems affects environmental conditions and ultimately alters the drinking water microbial composition and quality.

\subsection{Specific Building Plumbing System Conditions Alter Microbiological Water Quality}

Pipe diameters: Building plumbing pipes have small diameters, ranging between 1-2 $\mathrm{cm}$ (DN12-DN20), compared to diameters of 10-200 cm (DN100-DN2000) in the DWDS. This implies that the surface area within building plumbing systems is high compared to the corresponding water volume. For example, DN12 pipes have a surface area to volume (SA/V) ratio of $\sim 3: 1$, meaning for every $3 \mathrm{~cm}^{2}$ of pipe surface, there is approximately $1 \mathrm{~mL}$ of water (as opposed to the DWDS where $2 \mathrm{~mL}$ of water is in contact with $1 \mathrm{~cm}^{2}$ of pipe surface). This is particularly relevant, as an increasing SA/V ratio (e.g., from 1:2 in the DWDS to 3:1 in building plumbing systems) translates to a much higher potential impact of the biofilm on the water phase (e.g., due to detachment dynamics). Moreover, pipe diameters directly impact flow velocity and thus shear stress, with both increasing due to decreasing pipe diameters [44]. This is microbiologically relevant, as water dynamics impact both the dominance of specific bacteria [45] as well as biofilm structure and overall community compositions [46,47].

Temperature: Upon entering a building, temperature changes considerably as the water from the DWDS diverges into cold and warm water lines (Figure 2). After entering a building, cold water is subject to gradual warming (e.g., fluctuating between $8-20^{\circ} \mathrm{C}$ ) $[48,49]$, potentially favoring increased bacterial growth. Water in the warm water line is subject to a heat shock in the boiler (e.g., $60-63^{\circ} \mathrm{C}$ ) [48] and to severe temperature gradients along the building plumbing system, e.g., decreasing to below $30{ }^{\circ} \mathrm{C}$ within $1-3 \mathrm{~h}$ of stagnation [36]. One study showed that bacterial concentrations can be $20 \%$ higher in the cold water compared to the warm water [48]. Additionally, dissimilar community compositions have been found in warm and cold water, showing higher diversities at low temperatures and differences in abundant taxa between cold and warm water [15], [50]. Comparing the microbiology of associated cold and warm water in the same system highlights the impact that is introduced by installation design (e.g., pipe isolation) and the choice of operational settings (e.g., boiler temperature).

Stagnation time: In contrast to the DWDS, water stagnates for a significant amount of time in buildings. Here, user habits play an important role. Even though a building usually has a single owner, multiple inhabitants are using the installation, often in a variety of different and uncontrollable ways. For example, in a single family house, multiple people (a) use water for different purposes (e.g., showering, toilet flushing, laundry), (b) at different time points and in different frequencies, and (c) at different spatial locations in the building (e.g., tap in the bathroom on the upper floor vs. toilet in the basement) (e.g., [51]). These variations in operation result in highly irregular and uncontrollable water dynamics within a single building plumbing system and are, without the user's knowledge, 
inevitably impacting the microbiology thereof. Studies showed that stagnation results in an increase in bacterial cell concentrations in the water phase (e.g., from $\sim 6 \times 10^{4}$ to $\sim 1 \times 10^{5}$ cells $/ \mathrm{mL}$ during overnight stagnation [49]) as well as in community compositional changes, e.g., decreasing richness [14]. For some cases, the depletion of disinfectant residuals during stagnation was identified to be a reason for microbial changes [52], which ultimately resulted in drinking water deterioration [53].

Materials: Building plumbing systems consist of numerous types of very different materials. Here, not solely pipes but also components such as sealing rings, hoses, or fixtures are produced from a variety of metals as well as hard and flexible synthetic polymeric materials (Table 1). While this will be discussed in detail in Section 3, it is already important to notice that materials significantly impact the microbiology of building plumbing systems, e.g., due to different microbial colonization dynamics, based on surface properties [54] and nutrient migration [55,56].

Table 1. Materials used in building plumbing systems and their applications.

\begin{tabular}{ll}
\hline Material & Application \\
\hline Metals & \\
\hline Copper and copper alloys & Pipes and fittings \\
Brass (copper alloy) & Taps, valves, pipes, and fittings \\
Galvanized steel (GI) & Pipes and taps \\
Stainless steel & Fittings \\
Ductile iron & Pipes and fittings \\
Malleable iron & Nipples \\
Galvanized iron & Pipes and fittings \\
\hline Synthetic materials & \\
\hline Ethylene propylene diene monomer (EPDM) & O-rings, seals \\
Polyvinyl chloride (PVC) & \\
PVC-U (unplasticized) & Pipes and fittings \\
PVC-C (chlorinated) & Pipes and fittings \\
PVC-P (plasticized) & (Shower) hoses \\
Polyethylene (PE) & \\
PE-X (crosslinked; a, b, c) & Pipes (hot water pipes) \\
& Multilayer pipes \\
PE-RT (raised temperature resistant) & Pipes (hot water pipes) \\
Polybutylene (PB) & Multilayer pipes \\
Polypropylene (PP) & Pipes and fittings \\
PP-R (random Co-polymer) & \\
PP-C (Copolymer) & Tubes and fittings \\
PP-H (Holopolymer) & Tubes and fittings \\
Polyphenylsulfone (PPSU) & Tubes and fittings \\
Polyoxymethylen (POM) & Fittings \\
Polyvinylidene fluoride (PVDF) & Valve elements \\
Polytetrafluorethylen (PTFE; Teflon) & Fittings \\
Silicone rubber & Valve elements, seals \\
Epoxy resin & Seals \\
\hline & Inline coating \\
\hline
\end{tabular}

Importantly, all of the conditions above can be altered/managed either by operational adaptions (e.g., temperature, circulation) or design (e.g., materials, isolation), providing the opportunity to manage building plumbing microbiology proactively. Here, interventions will inevitably bring their own challenges and will need to be evaluated separately (e.g., increased operational costs due to higher water temperatures). In this review, we argue that the selection of good plumbing materials is one of the most straightforward starting points for a good building plumbing management. 


\section{Synthetic Polymeric Materials in Building Plumbing Systems}

\subsection{The Variety of Materials Used in Building Plumbing Systems Creates Numerous Ecological Niches}

Building plumbing originally consisted almost exclusively of metal-based products (copper, galvanized steel, etc.). However, during the last half-century, synthetic polymeric products were increasingly implemented (Figure 3A). The benefits of the latter are (1) the low cost, (2) an easier installation compared to rigid pipes, (3) high heat resistance, (4) long life-times, (5) corrosion resistance, and (6) better energy conservation due to reduced heat transfer and loss. A large variety of synthetic polymeric materials is used for both pipes and non-pipe components (Table 1). For example, cross-linked polyethylene (PE-X) and unplasticized polyvinyl chloride (PVC-U) are used for pipes. Fittings are often made from polybutylene (PB) and polypropylene (PP). Hoses are made from plasticized PVC (PVC-P), whereas ethylene propylene diene monomer (EPDM) and silicone rubber are typically used for the production of sealing materials. Importantly, there is not only substantially different material types within plumbing systems overall, but also within individual fixtures. For example, one single kitchen tap can comprise numerous different materials in contact with the water (e.g., galvanized steel, copper, PE-X, EPDM, and PVC-P; Figure 3B,C). It is important to realize that every single material potentially poses a unique environment and consequently creates a different niche for bacteria to grow.
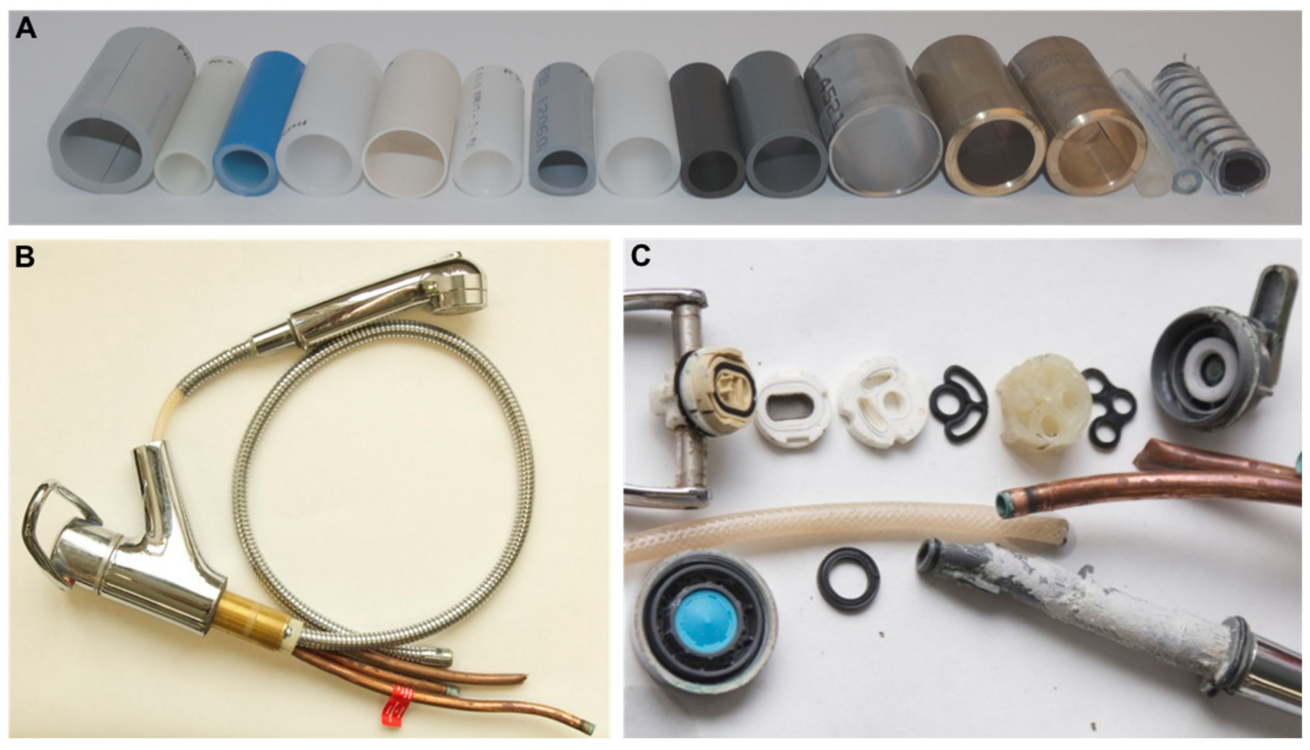

Figure 3. Variety of materials used within building plumbing systems and fixtures. (A) Different pipes and hoses from metals and both hard and flexible synthetic polymeric materials. (B,C) Materials used in a single kitchen tap.

\subsection{Carbon Migrates from Synthetic Polymeric Materials}

Organic carbon migration (or leaching) from the material into the water is a main reason why synthetic polymeric materials are relevant for microbial growth in buildings. Drinking water is typically carbon-limited with low concentrations of bioavailable organic carbon [57,58]. As a result, migrating carbon compounds increase the growth potential of a system. In most cases, the migrating substrates are not the polymers themselves, but rather the so-called additives (i.e., flexibilizers, plasticizers, stabilizers), which are added during production to improve or adapt specific properties of the material [59]. Stabilizers include antioxidants that protect the material against thermally introduced oxidation, i.e., increasing heat tolerance [60]. For example, Skjevrak et al. detected 2,4-di-tert-butyl-phenol (2,4-DTBP) in water running through HDPE pipes [60].

This compound was previously identified as a degradation by-product of Irgafos $168^{\circledR}$ (BASF, Switzerland [61]), an antioxidant used as an additive in PP pipes [62]. Plasticizers are added to 
polymeric materials to increase flexibility [63]. Here, the most commonly used plasticizers are phthalates, such as di-(2-ethylhexyl) phthalate (DEHP [64]). Due to its structure and polarity, PVC is particularly susceptible to the incorporation of plasticizers. Hence, many flexible hoses such as shower hoses are made from PVC with additional plasticizers. Importantly, these additives are usually low molecular-weight compounds, thus prone to leaching from the material into the water phase. Some of these compounds can serve as primary growth-supporting nutrient sources for bacteria [65] as they are easily biodegreadeble [66], leading to growth, biofilm formation, and ultimately affecting the microbial water quality.

Therefore, European Standards on the "influence of materials on water for human consumption" [67] include material testing with respect to both migration potential assays (e.g., KTW guideline, Germany [68]) as well as bacterial growth potential assays. For the latter, three different test methods are recognized [69], where microbial growth is measured by the mean dissolved oxygen demand (MDOD), volumetric measurements of total biofilm growth, or the determination of the biomass production potential (BPP) based on metabolic activity (i.e., ATP). An alternative method is the Swiss BioMig assay, introduced by Bucheli-Witschel et al. [56], which combines both migration and growth potential assays in a single test. This assay was, for example, used to evaluate and classify a range of different building plumbing materials [65], but also to study the impact of chlorination on the migration potential of biodegradable carbon [70]. Importantly, disinfectants such as chlorine were shown to impact plumbing materials and migration dynamics [71]. Then again, different materials affect the decay of disinfectant residuals to different extents [58]. Mao et al. [70] investigated the decay of chlorine when exposed to different synthetic polymeric materials. They found that chlorine concentrations were decreasing considerably; however, with rather low decay rate constants compared to non-flexible materials (e.g., EPDM 0.12/h versus copper 1.2/h [72]).

\subsection{Migrating Organic Carbon Compounds Drive Biofilm Formation and Selection}

Materials differ considerably in the quantity, composition, and dynamics of carbon migration [56]. For example, a study by Wen et al. [65] found that high-quality PE-X pipe material leaches less $(0.3 \mathrm{mg}$ TOC/L/d) total organic carbon (TOC) than flexibilized EPDM $(0.7 \mathrm{mg}$ TOC/L/d) or flexible PVC-P ( $40 \mathrm{mg}$ TOC/L/d) within the first $24 \mathrm{~h}$ of exposure. This study emphasizes the need for quality control of migrating carbon substances from plumbing materials. Especially shower hose materials are mainly made of flexible synthetic polymers (e.g., PVC-P), of which the exact chemical composition is normally not disclosed to the buyer and often not properly regulated by law. Consequently, shower hoses can be purchased in the whole spectrum of qualities: either high-quality and certified for drinking water use or low-quality and thus potentially leaching high carbon concentrations (see e.g., [73]). Proctor et al. [73] investigated the growth potential of migrating carbon compounds from five different flexible hose materials $(1 \times$ PE-X, $2 \times$ PVC-P, $1 \times$ silicone, and $1 \times$ unknown). All materials showed different degrees of carbon migration that (mostly) correlated with the actual growth within the corresponding hose. Carbon migration during material testing varied between $0.4-10.4 \mu \mathrm{g} \mathrm{C} / \mathrm{cm}^{2} /$ day and supported growth in a range of $0.5-4.8 \times 10^{7}$ cells $/ \mathrm{cm}^{2}$ in the same assay. Moreover, the diversity in the hose biofilm communities was shown to be at least 10-fold lower than in the corresponding water [73], highlighting the selectiveness of biofilm growth on flexible synthetic polymeric materials. While several studies observed such selective growth (e.g., [73,74]), it has barely (if at all) been explained on the basis of fundamental ecology. Studies from other research fields showed, however, that a change in the available carbon does alter microbial community composition [75], that this change is potentially due to differences in metabolic activities within the community [76], and that the one(s) that perform(s) best (growth rate and yield) will succeed and establish within the community [77]. Selective growth on different materials potentially impacts water quality. For example, several authors showed correlations between carbon migration of different materials, subsequent differences in bacterial growth, and differences in the establishment of Legionella pneumophila on those materials $[74,78]$. 
Importantly, the quantity of migrating carbon was shown to decrease considerably within days (to weeks). For example, Zhang and Liu [66] measured a decrease in migration from 0.25 to $<0.1 \mu \mathrm{g}$ $\mathrm{TOC} / \mathrm{d} / \mathrm{cm}^{2}$ already within the first 10 days of operation. This suggests that the impact of migrating carbon is the greatest in the early stages of biofilm development. This does not necessarily exclude carbon migration from having long-term impacts. Despite the fast decrease in migrating carbon concentrations early on, Lund et al. [71] showed that the migration can stay on a constant level for at least up to 12 months (with $0.2 \mathrm{mg} / \mathrm{m}^{2} / \mathrm{d}$ ). This suggests that, in addition to the highest impact right in the beginning, there might be a potential long-term influence on biofilm growth at least on a minor level. Consequently, we propose that the understanding of nutrient-based selection is essential for understanding and managing biofilm formation in building plumbing systems, particularly during the initial stages (e.g., during the commissioning of a new building).

\section{Quantifying Initial Biofilm Formation on Flexible Synthetic Polymeric Materials}

\subsection{Dispersal and Selection as Main Parameters for Initial Biofilm Formation}

Similar to other ecosystems, biofilm formation in building plumbing systems follows known ecological principles such as dispersal, selection, drift, and diversification $[79,80]$. This allows the quantification of biofilm formation processes to better understand growth dynamics. In this section, we specifically explore the importance of (1) water-to-surface dispersal and (2) nutrient-based selection through basic quantification of initial biofilm formation processes. For a theoretical example, we focus on the dynamics that follow the installation of a new shower hose-a common plumbing-maintenance action undertaken by most home owners at some point in time. The purpose of this example is to show that engineering information (e.g., material quality and system operation) can be combined with microbiological knowledge (e.g., attachment and growth data) to develop a quantitative understanding of biofilm formation in buildings. A typical shower hose $\left(\mathrm{L}=180 \mathrm{~cm}, \mathrm{~d}_{\mathrm{i}}=0.8 \mathrm{~cm}\right)$ is made from flexible PVC-P and has an inner surface area of $\sim 450 \mathrm{~cm}^{2}$ and a volume of $\sim 90 \mathrm{~mL}$. Five parameters that will govern the initial biofilm formation are: (1) The inorganic nutrients introduced daily with the drinking water, (2) the organic nutrients that migrate from the shower hose material into the water phase (see Section 3), (3) the ability and rate of bacteria to attach to the hose surface (water-to-surface dispersal), (4) the metabolic capability of bacteria to utilize the available nutrients and the rate at which they will grow, and (5) selection that occurs within the community due to the specific growth dynamics (nutrient-based selection). These parameters are not detached from each other but will, for the sake of clarity, be dealt with separately below.

1. Inorganic nutrients from the water: The tap water in this example is typical for Zurich $(\mathrm{CH})$, meaning non-chlorinated, biologically stable (i.e., assimilable organic carbon (AOC) $<10 \mu \mathrm{g} / \mathrm{L}$, [81]), oligotrophic water with approximately $1 \mathrm{mg} / \mathrm{L}$ dissolved organic carbon (DOC), $3 \mathrm{mg} / \mathrm{L}$ total nitrogen (TN), and $5 \mu \mathrm{g} / \mathrm{L}$ total phosphorous (TP) [82]. This converts to $0.1 \mathrm{mg}-\mathrm{TN} /$ hose and $0.5 \mu \mathrm{g}$-TP/hose.

2. Organics from the material: Flexible PVC-P leaches up to $4 \mu \mathrm{g}-\mathrm{TOC} / \mathrm{cm}^{2} /$ day, of which $\sim 50 \%$ is AOC (i.e., $2 \mu \mathrm{g}$-AOC $/ \mathrm{cm}^{2} /$ day) $[65,73]$. This converts to $\sim 900 \mu \mathrm{g}$-AOC/hose/day.

3. Water-to-surface dispersal: Zurich tap water comprises $\sim 5 \times 10^{4}$ cells $/ \mathrm{mL}$ (i.e., $4.5 \times 10^{6}$ cells/hose) and $>5000$ different bacterial taxa [50]. Water-to-surface dispersal rates for initial colonization remain poorly characterized for drinking water systems, but it is known that bacterial attachment starts within seconds to minutes of the first exposure $[83,84]$. Here, we assume an attachment of $1 \%$ of the total cell concentration (TCC) from the water phase during $1 \mathrm{~h}$ of stagnation, which means $\sim 1.1 \times 10^{6}$ cells/hose/day in the absence of any growth.

4. Bacterial growth: Based on a conversion factor of $10^{7}$ cells/ $\mu \mathrm{g}-\mathrm{AOC}[85,86]$ and following the rule-of-thumb for growth requirements of bacteria (i.e., a C:N:P ratio of 100:10:1 [85]), bacterial growth in the water would be carbon-limited (allowing for the growth of $\sim 9 \times 10^{6}$ cells/hose/day). However, this is reversed due to the excessive AOC that migrates continuously from the material, 
rendering the shower-hose environment phosphorous-limited. Ultimately, the maximum growth potential of the combined system (i.e., water and hose) is $\sim 1 \times 10^{8}$ cells/hose/day, assuming that $100 \%$ of the phosphorous is biologically available.

5. Nutrient-based selection: The composition and biodiversity of biofilm communities is influenced by the type of material they grow on [87]. Based on the selection observed in previous studies, we assume for our example that only $10 \%$ of the bacteria present in the water phase and of those dispersing to the material's surface can actually utilize the migrated organic carbon and grow (i.e., $4.5 \times 10^{5}$ cells/hose/day).

\subsection{Initial Colonization, Growth, and Biofilm Formation}

In Figure 4, we demonstrate the calculated dynamics of initial biofilm formation on a new material, based on the example discussed above.

We calculated planktonic and biofilm growth during the first $72 \mathrm{~h}$ of operation with intermittent flushing events occurring every $24 \mathrm{~h}$ (Figure $4 \mathrm{~A}$ ). The calculation is based on (1) TP from the water being replenished with every 24-hour flushing event and (2) continuous carbon migration from the material with unutilized compounds being removed with every flushing event (Figure 4B). Within each 24 h-cycle, (3) a fraction of the planktonic cells will attach to the material's surface (water-to-surface dispersal) and (4) some will grow in both the planktonic and biofilm phase. This will (5) benefit growing taxa over others, resulting in a nutrient-based selection within the community.

For the calculation of planktonic growth, we used the following equation (Equation 1):

$$
\operatorname{pTCC}_{\mathrm{t}}=\left(\left(\operatorname{pTCC}_{0} \cdot(1-r)\right)+\left(\left(\operatorname{pTCC}_{0} \cdot r\right) \cdot(1+\mu)^{\mathrm{t}}\right)\right)-\left(\left(\left(\operatorname{pTCC}_{0} \cdot r\right) \cdot(1+\mu)^{\mathrm{t}}\right) \cdot k_{a}\right)
$$

with $\mathrm{pTCC}_{\mathrm{t}}$ representing the number of planktonic bacteria in the water phase at a certain time-point $\mathrm{t}$, based on a fraction of growing cells $r=0.1$ (i.e., 10\% grow) for the originally (i.e., with each flushing event) introduced cells ( pTCC $_{0}$ ), with a constant growth rate of $\mu=0.125 / \mathrm{h}$ and taking a constant attachment into consideration, with the attachment rate coefficient $k_{a}=0.01 / \mathrm{h}$.

For calculating biofilm growth, an adapted equation was used (Equation (2)):

$$
\operatorname{sTCC}_{\mathrm{t}}=\left(\operatorname{sTCC}_{\mathrm{t}-1} \cdot(1+\mu)\right)+\left(\left(\left(\operatorname{pTCC}_{0} \cdot r\right) \cdot(1+\mu)^{\mathrm{t}}\right) \cdot k_{a}\right)
$$

with $\mathrm{sTCC}_{\mathrm{t}}$ representing the number of bacteria in the biofilm phase at a certain time-point $t$, based on a fraction of growing cells $r=0.1$ for the originally introduced cells ( $\mathrm{pTCC}_{0}$ ), with a constant growth rate of $\mu=0.125 / \mathrm{h}$ and taking a constant attachment into consideration, with $k_{a}=0.01 / \mathrm{h}$.

Applying this to input variables shows the following (Figure 4C):

1. During the first stagnation period, i.e., within the first $24 \mathrm{~h}$ of stagnation, planktonic growth dominates the shower hose system, with $1.2 \times 10^{7}$ planktonic $(86 \%)$ and $1.8 \times 10^{6}$ attached $(14 \%)$ cells/hose. However, in the subsequent day(s) (with daily shower/flushing events), the water phase is exchanged every $24 \mathrm{~h}$, meaning a replacement of the grown planktonic cells by the source water community, and a replenishment of inorganic nutrients in the otherwise carbon-rich environment. Sessile cells remain in the biofilm and therefore continue growing at the concentration of $\mathrm{sTCC}_{24}$ after the first flushing event, subsequently rendering the system biofilm dominated; with $1 \times 10^{7}$ pTCC/hose $(26 \%)$ versus $3 \times 10^{7}$ sTCC/hose $(74 \%)$ after $48 \mathrm{~h}$.

2. Assuming continuous growth in the biofilm, the shower hose system will reach phosphorous-limitation after approximately $70 \mathrm{~h}$ (Figure 4B), limiting further growth until a replenishment of inorganic nutrients.

3. During the initial stagnation period, the biofilm community is dominated by the initial water-to-surface dispersal-driven colonization. However, the continuous growth of adapted cells in the biofilm results in a highly selective growth and biofilm development. More precisely, the original drinking water community in our example comprised around 5000 different species. 
Due to the ability of (initially) only $10 \%$ to grow (i.e., 500 species), species heterogeneity in the biofilm inevitably declines. As a result, we can state that nutrient-based selection is important for the subsequent development of the biofilm and its microbial community composition.
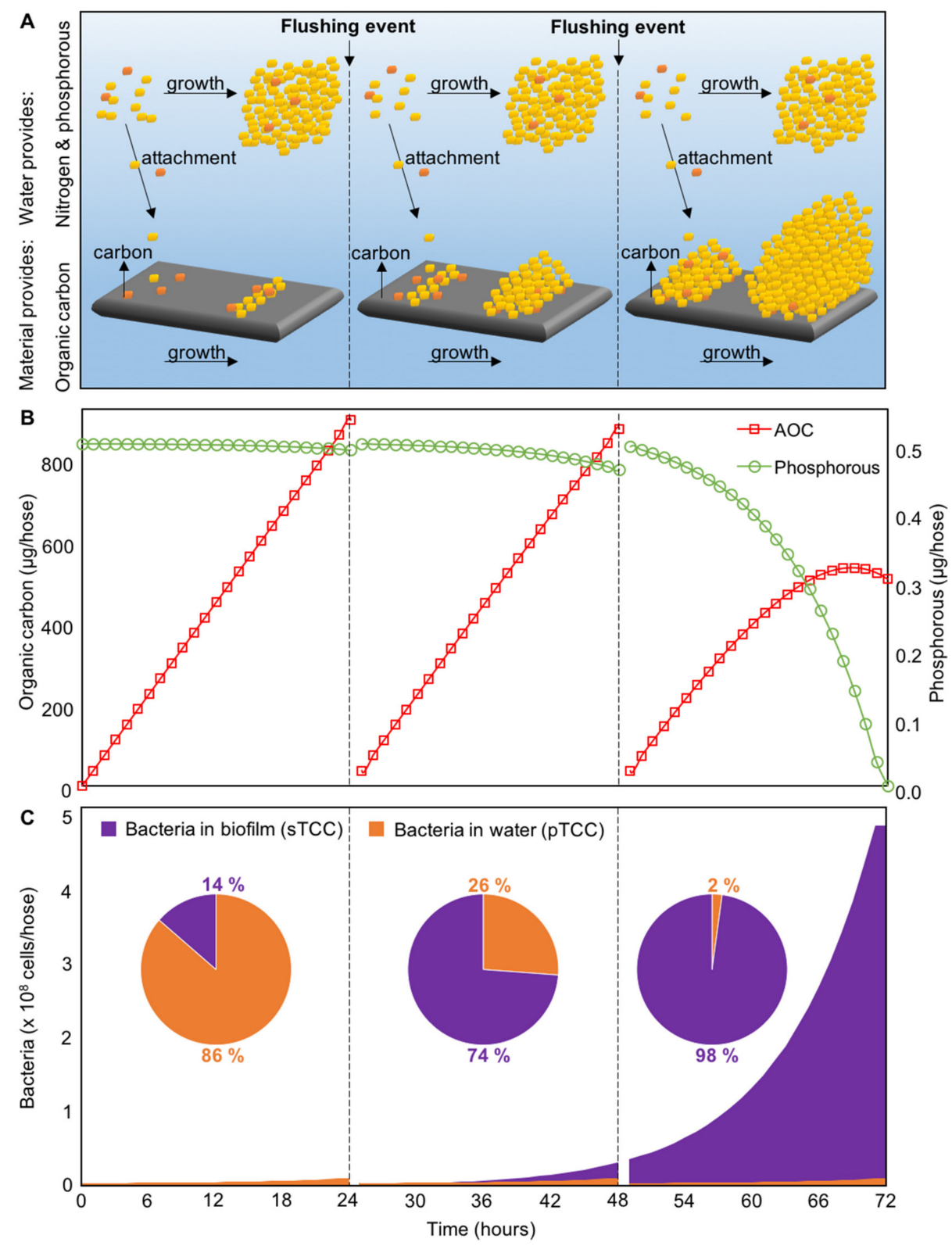

Figure 4. Theoretical example of initial biofilm formation on a new flexible synthetic polymeric material (e.g., PVC-P shower hose). (A) Visualization of the initial stages of biofilm formation, driven by attachment (water-to-surface dispersal) and (nutrient-based selective) growth. (B) Nutrient concentrations with phosphorous deriving from the water and assimilable organic carbon (AOC) migrating from the material. (C) Quantification of bacterial growth, showing rapid domination of the biofilm in the overall distribution of bacteria.

Details and absolute values of this initial biofilm formation "model" will certainly vary between locations. However, we argue that the basic concept will be the same. Consequently, these quantitative considerations are important as (1) bacterial/biofilm growth within building plumbing systems (and here especially on low-quality flexible materials) is relevant regarding drinking water quality and (2) knowledge on such ecological factors opens management options. 


\section{The Relevance and Management of Building Plumbing Biofilms}

To be able to ensure high-quality drinking water until the point of consumption requires the understanding of basic principles of microbial ecology, as well as the collaboration and interplay between various disciplines and stakeholders (e.g., material producers, plumbers, planners, architects, home owners, and scientists).

\subsection{Why Should We Care?}

A lack in understanding bacterial growth in building plumbing systems equals a lack of control and can result in aesthetic, operational, and/or hygienic problems. Aesthetic and operational problems often manifest in costumer dissatisfaction involving taste, odor, color, particles, or water pressure; all of which potentially indicate water quality deterioration [88]. Hygienic problems are particularly relevant, as the number of building plumbing related waterborne disease incidents increased over the last decades. A good example is the worldwide increase in Legionnaires' disease incidents, for example in the US (4.5-fold between 2000-2015 [89]) and Switzerland (four-fold between 2000-2015 [90]). The causative organism, Legionella pneumophila, is thriving in building plumbing systems, especially in biofilms [91]. Additionally, opportunistic pathogens such as Pseudomonas aeruginosa and Mycobacterium avium were shown to grow preferably in building plumbing systems [92]. For example, a nation-wide German study in 2010 detected Pseudomonas sp. above the legal limit (0 CFU/100 mL) in approximately 3\% of all drinking water samples taken $(\mathrm{n}=3468)$ [93]. The relevance of increasing Pseudomas aeruginosa appearances has been discussed by Bédard et al. [94], highlighting not only their capability of incorporation in building plumbing biofilms but also the emerging health risk for susceptible people, e.g., cystic fibrosis patients. M. avium has, for example, been found to colonize shower heads, with $20 \%$ positive samples in a survey study by Feazel et al. [95] ( $n=52$ samples from 42 different sampling sites). This is critical as M. avium is an agent of pulmonary disease, leaving the inhalation of shower water droplets and aerosols as a major transfer route and risk area [96,97].

To emphasize this point, all of the opportunistic pathogens mentioned above are commonly detected in building plumbing biofilms [33]. However, to date, a connection between properties of materials and pathogenic growth is only done sporadically. One example by Wen et al. [65] used a pathogen growth potential assay [98], which illustrated the ability of selected pathogens to grow on migrated compounds as sole carbon sources. Additionally, previous studies showed: (1) that the number of growing bacteria increases with decreasing material quality (e.g., $\mathrm{PEX}_{\mathrm{c}}<\mathrm{EPDC}_{\text {certified }}<$ $\mathrm{EPDM}_{\text {non-certified }}$ ) and (2) that an increase in bacterial numbers correlates with a higher concentrations of L. pneumophila $[74,78]$. However, to date, no clear correlations between specific materials and specific pathogens have been established.

\subsection{What Can We Do?}

One straightforward microbial management strategy for new building plumbing systems is to limit the overall use components that are made by default from lower quality materials (e.g., hoses, sealing rings) and only use the highest quality materials for specific applications (Table 1). This strategy depends on (1) proper microbial quality control for all materials in contact with drinking water, (2) knowledge exchange between all stakeholders to raise awareness of microbiological relevance and hygienic issues in building plumbing, and (3) further research to develop a better understanding of the microbial ecology of building plumbing systems.

1. A quality label for good materials: Important for the widespread use of high-quality materials are sensible and standardized quality control procedures. Irrespective of legal guidelines, assays for the assessment of carbon migration and growth potential exist (Section 3 [69]) and can be used by both material producers and policy makers. The result would be a material-grading system that is ideally freely available to all stakeholders, including plumbers, planners, and architects. This material grading system can, for example, be in form of a quality label, which enables 
easy identification of high-quality materials for both professional and private costumers. Here, the incentive for producers would be the competitive advantage gained over lower quality products from competitors.

2. Information sharing: To address microbiological challenges requires extensive information sharing between the diverse stakeholders in building plumbing systems. Here, scientists have an opportunity to contribute knowledge on how the basic principles in microbial ecology relates to different plumbing materials and ultimately water quality. One example can be to incorporate microbiology courses in basic training and teaching modules for plumbers and architects. On a different level, opportunities exist to collaborate with producers of plumbing materials and fixtures on applied research projects focusing on the evaluation of (existing) material properties, their interaction with microorganisms, and their dependency on environmental conditions in buildings. Finally, it is important to engage the public as the end-users who are operating the building plumbing systems and therefore create the conditions that influence material behavior and microbiological growth potential. Elucidating the impact of low-quality materials on drinking water microbial quality will incentivize users to invest in high-quality materials, for example, when purchasing a new shower hose or fixture.

3. Further research: Considerable knowledge gaps exist in our understanding of the microbial ecology of building plumbing systems. There is a clear need for additional pilot- and full-scale experiments dealing with the interplay between existing materials, the developing microbial community, and water quality. More precisely, a better understanding is needed of a materials' behavior in the context of complex building plumbing systems (e.g., fluctuating water temperatures, stagnation, disinfectant residuals, different materials in concert, etc.). Additionally, it is still completely unclear whether material-specific microbial communities establish when similar plumbing materials are used in different locations, or what exactly the impact of source water differences (e.g., community composition) are on the microbiome development. In a similar vein, research is needed on whether specific materials (additives) favor the establishment of specific opportunistic pathogens. Finally, with respect to building plumbing, there are clear research opportunities in the field of new material design/development. On the one hand, there is interest in developing anti-microbial strategies focusing on surface-coatings (e.g., copper or silver [99]). Similarly, there is ongoing research on materials with anti-adhesive properties to combat fouling [100]. On the other hand, we propose that material design might also move towards exploring the management of a "good," stable microbial community composition. In this regard, Wang et al. [65] proposed a probiotic approach in which they would introduce specific bacteria into the building plumbing system, potentially coupled with a prebiotic approach of creating favorable conditions for such organisms in building plumbing systems. With respect to the latter, one option would be to tailor the leaching properties of a specific material (nutrient type, rate) to selected probiotic microorganisms in order to sustain their presence/dominance in a plumbing system.

\section{Conclusions}

- Conditions within building plumbing systems impact and change the microbial community composition of the water, potentially resulting in quality deterioration.

- Flexible synthetic materials leach organic carbon, which not only increases the potential for bacterial growth but also drives selection within the establishing biofilm community.

- Ecological principles can be used to understand and quantify microbial growth dynamics and their dependency on engineered components of plumbing systems.

- Gaining and sharing knowledge on the interaction between material properties and microbiology provides stakeholders with the possibility to actively manage building plumbing microbiology through material design, material selection, and operation. 
- The exclusive use of high-quality materials in new building plumbing systems poses a straightforward strategy towards managing the building plumbing microbiome.

Author Contributions: Conceptualization, L.N. and F.H.; writing-original draft preparation, L.N. and F.H.; writing-review and editing, L.N. and F.H. All authors have read and agreed to the published version of the manuscript.

Funding: This work was funded by the Swiss National Science Foundation, SNSF grant number 31003A_163366/1.

Acknowledgments: The authors thank Roland Widler (formerly Geberit International AG; Jona, Switzerland) and Marcel Lüscher (formerly GF JRG AG, Sissach, Switzerland) for their professional input on building plumbing materials and their applications (Table 1).

Conflicts of Interest: The authors declare no conflict of interest.

\section{References}

1. Proctor, C.R.; Hammes, F. Drinking Water Microbiology-From Measurement to Management. Curr. Opin. Biotechnol. 2015, 33, 87-94. [CrossRef] [PubMed]

2. Hammes, F.; Berney, M.; Wang, Y.; Vital, M.; Koster, O.; Egli, T. Flow-Cytometric Total Bacterial Cell Counts as a Descriptive Microbiological Parameter for Drinking Water Treatment Processes. Water Res. 2008, 42, 269-277. [CrossRef] [PubMed]

3. Rinta-Kanto, J.M.; Lehtola, M.J.; Vartiainen, T.; Martikainen, P.J. Rapid Enumeration of Virus-like Particles in Drinking Water Samples Using SYBR Green I-Staining. Water Res. 2004, 38, 2614-2618. [CrossRef] [PubMed]

4. Vital, M.; Dignum, M.; Magic-Knezev, A.; Ross, P.; Rietveld, L.; Hammes, F. Flow Cytometry and Adenosine Tri-Phosphate Analysis: Alternative Possibilities to Evaluate Major Bacteriological Changes in Drinking Water Treatment and Distribution Systems. Water Res. 2012, 46, 4665-4676. [CrossRef]

5. Besmer, M.D.; Hammes, F. Short-Term Microbial Dynamics in a Drinking Water Plant Treating Groundwater with Occasional High Microbial Loads. Water Res. 2016, 107, 11-18. [CrossRef]

6. Stadler, H.; Klock, E.; Skritek, P.; Mach, R.L.; Zerobin, W.; Farnleitner, A.H. The Spectral Absorption Coefficient at 254nm as a Real-Time Early Warning Proxy for Detecting Faecal Pollution Events at Alpine Karst Water Resources. Water Sci. Technol. 2010, 62, 1898-1906. [CrossRef]

7. Jung, A.-V.; Le Cann, P.; Roig, B.; Thomas, O.; Baurè, E.; Thomas, M.-F. Microbial Contamination Detection in Water Resources: Interest of Current Optical Methods, Trends and Needs in the Context of Climate Change. Int. J. Environ. Res. Public Health 2014, 11, 4292-4310. [CrossRef]

8. Ma, X.; Vikram, A.; Casson, L.; Bibby, K. Centralized Drinking Water Treatment Operations Shape Bacterial and Fungal Community Structure. Environ. Sci. Technol. 2017, 51, 7648-7657. [CrossRef]

9. Bruno, A.; Sandionigi, A.; Bernasconi, M.; Panio, A.; Labra, M.; Casiraghi, M. Changes in the Drinking Water Microbiome: Effects of Water Treatments Along the Flow of Two Drinking Water Treatment Plants in a Urbanized Area, Milan (Italy). Front. Microbiol. 2018, 9, 2557. [CrossRef]

10. Pinto, A.J.; Xi, C.; Raskin, L. Bacterial Community Structure in the Drinking Water Microbiome Is Governed by Filtration Processes. Environ. Sci. Technol. 2012, 46, 8851-8859. [CrossRef]

11. Niquette, P.; Servais, P.; Savoir, R. Bacterial Dynamics in the Drinking Water Distribution System of Brussels. Water Res. 2001, 35, 675-682. [CrossRef]

12. Henne, K.; Kahlisch, L.; Brettar, I.; Höfle, M.G. Analysis of Structure and Composition of Bacterial Core Communities in Mature Drinking Water Biofilms and Bulk Water of a Citywide Network in Germany. Appl. Environ. Microbiol. 2012, 78, 3530-3538. [CrossRef] [PubMed]

13. Lührig, K.; Canback, B.; Paul, C.J.; Johansson, T.; Persson, K.M.; Radström, P. Bacterial Community Analysis of Drinking Water Biofilms in Southern Sweden. Microbes Environ. 2015, 30, 99-107. [CrossRef] [PubMed]

14. Ling, F.; Whitaker, R.; LeChevallier, M.W.; Liu, W.-T. Drinking Water Microbiome Assembly Induced by Water Stagnation. ISME J. 2018, 12, 1520-1531. [CrossRef] [PubMed]

15. Ji, P.; Rhoads, W.J.; Edwards, M.A.; Pruden, A. Impact of Water Heater Temperature Setting and Water Use Frequency on the Building Plumbing Microbiome. ISME J. 2017, 11, 1318-1330. [CrossRef]

16. Inkinen, J.; Kaunisto, T.; Pursiainen, A.; Miettinen, I.T.; Kusnetsov, J.; Riihinen, K.; Keina, M.M. Drinking Water Quality and Formation of Biofilms in an Office Building during Its First Year of Operation, a Full Scale Study. Water Res. 2014, 9, 83-91. [CrossRef] 
17. Liu, G.; Bakker, G.L.; Li, S.; Vreeburg, J.H.; Verberk, J.Q.; Medema, G.J.; Liu, W.T.; Van Dijk, J.C. Pyrosequencing Reveals Bacterial Communities in Unchlorinated Drinking Water Distribution System: An Integral Study of Bulk Water, Suspended Solids, Loose Deposits, and Pipe Wall Biofilm. Environ. Sci. Technol. 2014, 48, 5467-5476. [CrossRef]

18. Wingender, J.; Flemming, H.-C. Contamination Potential of Drinking Water Distribution Network Biofilms. Water Sci. 2004, 49, 277-286. [CrossRef]

19. Lehtola, M.J.; Miettinen, I.T.; Keina, M.M.; Kekki, T.K.; Laine, O.; Hirvonen, A.; Vartiainen, T.; Martikainen, P.J. Microbiology, Chemistry and Biofilm Development in a Pilot Drinking Water Distribution System with Copper and Plastic Pipes. Water Res. 2004, 38, 3769-3779. [CrossRef]

20. Departement of Industrial Plants. Drinking water distribution, City of Zurich. Available online: https: //www.stadt-zuerich.ch/dib/de/index/wasserversorgung/trinkwasser.html (accessed on 31 August 2019).

21. Liu, J.; Ren, H.; Ye, X.; Wang, W.; Liu, Y.; Lou, L.; Cheng, D.; He, X.; Zhou, X.; Qiu, S.; et al. Bacterial Community Radial-Spatial Distribution in Biofilms along Pipe Wall in Chlorinated Drinking Water Distribution System of East China. Appl. Microbiol. Biotechnol. 2017, 101, 749-759. [CrossRef]

22. EU Comission, D.W.D. DWD 98/83/EC. Off. J. Eur. Communities 1998, 41, 54.

23. EPA. SAFE DRINKING WATER ACT (SDWA); EPA: Washington, DC, USA, 2018; pp. 1-144.

24. Prest, E.I.; Hammes, F.; van Loosdrecht, M.C.M.; Vrouwenvelder, J.S. Biological Stability of Drinking Water: Controlling Factors, Methods, and Challenges. Front. Microbiol. 2016, 7, 45. [CrossRef] [PubMed]

25. Nescerecka, A.; Rubulis, J.; Vital, M.; Juhna, T.; Hammes, F. Biological Instability in a Chlorinated Drinking Water Distribution Network. PLoS ONE 2014, 9, e96354. [CrossRef] [PubMed]

26. Prest, E.I.; Weissbrodt, D.G.; Hammes, F.; Van Loosdrecht, M.C.M.; Vrouwenvelder, J.S. Long-Term Bacterial Dynamics in a Full-Scale Drinking Water Distribution System. PLoS ONE 2016, e0164445. [CrossRef] [PubMed]

27. McCoy, S.T.; Vanbriesen, J.M.; Asce, M. Temporal Variability of Bacterial Diversity in a Chlorinated Drinking Water Distribution System. J. Environ. Eng. 2012, 138, 786-795. [CrossRef]

28. Stanish, L.F.; Hull, N.M.; Robertson, C.E.; Harris, J.K.; Stevens, M.J.; Spear, J.R.; Pace, N.R. Factors Influencing Bacterial Diversity and Community Composition in Municipal Drinking Waters in the Ohio River Basin, USA. PLoS ONE 2016, 11, e0157966. [CrossRef]

29. Potgieter, S.; Pinto, A.; Sigudu, M.; du Preez, H.; Ncube, E.; Venter, S. Long-Term Spatial and Temporal Microbial Community Dynamics in a Large-Scale Drinking Water Distribution System with Multiple Disinfectant Regimes. Water Res. 2018, 139, 406-419. [CrossRef]

30. Haig, S.; Kotlarz, N.; Lipuma, J.J.; Raskin, L. A High-Throughput Approach for Identification of Nontuberculous Mycobacteria in Drinking Water Reveals Relationship between Water Age and Mycobacterium avium. MBio 2018, 9, e02354-17. [CrossRef]

31. LeChevallier, M.W.; Welch, N.J.; Smith, D.B. Full-Scale Studies of Factors Related to Coliform Regrowth in Drinking Water. Appl. Environ. Microbiol. 1996, 62, 2201-2211. [CrossRef]

32. Buse, H.Y.; Lu, J.; Lu, X.; Mou, X.; Ashbolt, N.J. Microbial Diversities (16S and 18S rRNA Gene Pyrosequencing) and Environmental Pathogens within Drinking Water Biofilms Grown on the Common Premise Plumbing Materials Unplasticized Polyvinylchloride and Copper. FEMS Microbiol. Ecol. 2014, 88, 280-295. [CrossRef]

33. Williams, M.M.; Armbruster, C.R.; Arduino, M.J. Plumbing of Hospital Premises Is a Reservoir for Opportunistically Pathogenic Microorganisms: A Review. Biofouling 2013, 29, 147-162. [CrossRef] [PubMed]

34. Moritz, M.M.; Flemming, H.C.; Wingender, J. Integration of Pseudomonas Aeruginosa and Legionella Pneumophila in Drinking Water Biofilms Grown on Domestic Plumbing Materials. Int. J. Hyg. Environ. Health 2010, 213, 190-197. [CrossRef] [PubMed]

35. Zlatanovic, L.; Van Der Hoek, J.P.; Vreeburg, J.H.G. An Experimental Study on the in Fl Uence of Water Stagnation and Temperature Change on Water Quality in a Full-Scale Domestic Drinking Water System. Water Res. 2017, 123, 761-772. [CrossRef]

36. Bédard, E.; Laferrière, C.; Déziel, E.; Prévost, M. Impact of Stagnation and Sampling Volume on Water Microbial Quality Monitoring in Large Buildings. PLoS ONE 2018, e0199429. [CrossRef]

37. Trinkwasserverordnung und Legionellen. Available online: https://www.bundesgesundheitsministerium. de/fileadmin/Dateien/3_Downloads/T/Trinkwasserverordnung/Stammtext_TrinkwV_und_Legionellen_ 250418.pdf (accessed on 31 August 2019). 
38. Bundesministerium für Wirtschaft. Verordnung Über Allgemeine Bedingungen Für Die Versorgung Mit Wasser (AVBWasserV). 2014, 1980. Available online: https://www.gesetze-im-internet.de/avbwasserv/ BJNR007500980.html (accessed on 31 August 2019).

39. Open Data Zürich. Gebäude und Wohnungen nach Gebäudeart und Stadtquartier seit 2008. Available online: https://data.stadt-zuerich.ch/dataset/bau_best_geb_whg_bev_gebaeudeart_quartier_seit2008 (accessed on 31 August 2019).

40. Liu, G.; Van der Mark, E.J.; Verberk, J.Q.; Van Dijk, J.C. Flow Cytometry Total Cell Counts: A Field Study Assessing Microbiological Water Quality and Growth in Unchlorinated Drinking Water Distribution Systems. Biomed. Res. Int. 2013, 2013, 595872. [CrossRef]

41. Lin, S.; Wang, X.; Chao, Y.; He, Y.; Liu, M. Predicting Biofilm Thickness and Biofilm Viability Based on the Concentration of Carbon-Nitrogen-Phosphorus by Support Vector Regression. Environ. Sci. Pollut. Res. 2016, 23, 418-425. [CrossRef]

42. Prévost, M.; Rompré, A.; Coallier, J.; Servais, P.; Laurent, P.; Clément, B.; Lafrance, P. Suspended Bacterial Biomass and Activity in Full-Scale Drining Water Distribution Systems: Impact of Water Treatment. Water Res. 1998, 32, 1393-1406. [CrossRef]

43. Liu, R.; Zhu, J.; Yu, Z.; Joshi, D.; Zhang, H.; Lin, W.; Yang, M. Molecular Analysis of Long-Term Biofilm Formation on PVC and Cast Iron Surfaces in Drinking Water Distribution System. J. Environ. Sci. 2014, 26, 865-874. [CrossRef]

44. Kim, J.; Kim, H.; Han, S.; Lee, J.; Oh, J.; Chung, S.; Park, H.-D. Hydrodynamic Effects on Bacterial Biofilm Development in a Microfluidic Environment. RSC Publ. 2013, 13, 1846-1849. [CrossRef]

45. Fang, H.; Chen, Y.; Huang, L.; He, G. Analysis of Biofilm Bacterial Communities under Different Shear Stresses Using Size-Fractionated Sediment. Sci. Rep. 2017, 7, 1-14. [CrossRef] [PubMed]

46. Douterelo, I.; Sharpe, R.L.; Boxall, J.B. Influence of Hydraulic Regimes on Bacterial Community Structure and Composition in an Experimental Drinking Water Distribution System. Water Res. 2013, 47, 503-516. [CrossRef] [PubMed]

47. Fish, K.; Osborn, A.M.; Boxall, J.B. Biofilm Structures (EPS and Bacterial Communities) in Drinking Water Distribution Systems Are Conditioned by Hydraulics and Influence Discolouration. Sci. Total Environ. 2017, 593-594, 571-580. [CrossRef]

48. Henne, K.; Kahlisch, L.; Ho, M.G.; Brettar, I. Seasonal Dynamics of Bacterial Community Structure and Composition in Cold and Hot Drinking Water Derived from Surface Water Reservoirs. Water Res. 2013, 47, 5614-5630. [CrossRef] [PubMed]

49. Lautenschlager, K.; Boon, N.; Wang, Y.; Egli, T.; Hammes, F. Overnight Stagnation of Drinking Water in Household Taps Induces Microbial Growth and Changes in Community Composition. Water Res. 2010, 44, 4868-4877. [CrossRef]

50. Proctor, C.R.; Reimann, M.; Vriens, B.; Hammes, F. Biofilms in Shower Hoses. Water Res. 2018, 131, $274-286$. [CrossRef]

51. Moerman, A.; Blokker, M.; Vreeburg, J.; Van Der Hoek, J.P. Drinking Water Temperature Modelling in Domestic Systems. Procedia Eng. 2014, 89, 143-150. [CrossRef]

52. Nguyen, C.; Elfland, C.; Edwards, M. Impact of Advanced Water Conservation Features and New Copper Pipe on Rapid Chloramine Decay and Microbial Regrowth. Water Res. 2011, 46, 611-621. [CrossRef]

53. Rhoads, W.J.; Pruden, A.; Edwards, M.A. Survey of Green Building Water Systems Reveals Elevated Water Age and Water Quality Concerns. Environ. Sci. Water Res. Technol. 2016, 2, 164-173. [CrossRef]

54. Hogt, A.H.; Dankert, J.; Feijen, J. Adhesion of Staphylococcus Epidermidis and Staphylococcus Saprophyticus to a Hydrophobic Biomaterial. J. Gen. Microbiol. 1985, 131, 2485-2491. [CrossRef]

55. Connell, M.; Stenson, A.; Weinrich, L.; Lechevallier, M.; Boyd, S.L.; Ghosal, R.R.; Dey, R.; Whelton, A.J. PEX and PP Water Pipes: Assimilable Carbon, Chemicals, and Odors. J. Am. Water Works Assoc. 2016, 108, E192-E204. [CrossRef]

56. Bucheli-Witschel, M.; Koetzsch, S.; Darr, S.; Widler, R.; Egli, T. A New Method to Assess the Influence of Migration from Polymeric Materials on the Biostability of Drinking Water. Water Res. 2012, 46, 4246-4260. [CrossRef] [PubMed]

57. Krzeminski, P.; Vogelsang, C.; Meyn, T.; Köhler, S.J.; Poutanen, H.; de Wit, H.A.; Uhl, W. Natural Organic Matter Fractions and Their Removal in Full-Scale Drinking Water Treatment under Cold Climate Conditions in Nordic Capitals. J. Environ. Manag. 2019, 241, 427-438. [CrossRef] [PubMed] 
58. Park, S.K.; Lee, S.H.; Choi, S.C.; Kim, K. Characteristics of Biofilm Community Formed in the Chlorinated Biodegradable Organic Matter-Limited Tap Water. Environ. Technol. 2006, 27, 377-386. [CrossRef] [PubMed]

59. Schiller, M. PVC Additives; Carl Hanser Verlag: München, Germany, 2015.

60. Skjevrak, I.; Due, A.; Gjerstad, K.O.; Herikstad, H. Volatile Organic Components Migrating from Plastic Pipes (HDPE, PEX and PVC) into Drinking Water. Water Res. 2003, 37, 1912-1920. [CrossRef]

61. BASF. Irgafos@168. 2010. Available online: http://www.mohe021.com/uploads/soft/180202/TDS_Irgafos168_e.pdf (accessed on 31 August 2019).

62. Löschner, D.; Rapp, T.; Schlosser, F.U.; Schuster, R.; Stottmeister, E.; Zander, S. Experience with the Application of the Draft European Standard prEN 15768 to the Identification of Leachable Organic Substances from Materials in Contact with Drinking Water by GC-MS. Anal. Methods 2011, 3, 2547-2556. [CrossRef]

63. Graham, P.R. Phthalate Ester Plasticizers-Why and How They Are Used. Environ. Health Perspect. 1973, 3, 3-12.

64. Erythropel, H.C.; Maric, M.; Nicell, J.A.; Leask, R.L.; Yargeau, V. Leaching of the Plasticizer di(2-Ethylhexyl)phthalate (DEHP) from Plastic Containers and the Question of Human Exposure. Appl. Microbiol. Biotechnol. 2014, 98, 9967-9981. [CrossRef]

65. Wen, G.; Koetzsch, S.; Vital, M.; Egli, T.; Ma, J. BioMig-A Method to Evaluate the Potential Release of Compounds from and the Formation of Biofilms on Polymeric Materials in Contact with Drinking Water. Environ. Sci. Technol. 2015, 49, 11659-11669. [CrossRef]

66. Zhang, L.; Liu, S. Investigation of Organic Compounds Migration from Polymeric Pipes into Drinking Water under Long Retention Times. Procedia Eng. 2014, 70, 1753-1761. [CrossRef]

67. BSI. Influence of Materials on Water for Human Consumption Enhancement of Microbial Growth (EMG); BS EN 16421:2014; BSI: London, UK, 2014.

68. Umweltbundesamt. Leitlinie Zur Hygienischen Beurteilung von Organischen Materialien Im Kontakt Mit Trinkwasser; Umweltbundesamt: Dessau-Roßlau, Germany, 2016.

69. Koetzsch, S.; Egli, T. Kunststoffe in Kontakt Mit Trinkwasser. Aqua Gas 2016, 3, 44-52.

70. Mao, G.; Wang, Y.; Hammes, F. Short-Term Organic Carbon Migration from Polymeric Materials in Contact with Chlorinated Drinking Water. Sci. Total Environ. 2018, 613-614, 1220-1227. [CrossRef] [PubMed]

71. Lund, V.; Anderson-Glenna, M.; Skjevrak, I.; Steffensen, I.L. Long-Term Study of Migration of Volatile Organic Compounds from Cross-Linked Polyethylene (PEX) Pipes and Effects on Drinking Water Quality. J. Water Health 2011, 9, 483-497. [CrossRef] [PubMed]

72. Zheng, M.; He, C.; He, Q. Fate of Free Chlorine in Drinking Water during Distribution in Premise Plumbing. Ecotoxicology 2015, 24, 2151-2155. [CrossRef] [PubMed]

73. Proctor, C.R.; Gächter, M.; Kötzsch, S.; Rölli, F.; Sigrist, R.; Walser, J.-C.; Hammes, F. Biofilms in Shower Hoses-Choice of Pipe Material Influences Bacterial Growth and Communities. Environ. Sci. Water Res. Technol. 2016, 2, 670-682. [CrossRef]

74. Van der Kooij, D.; van der Wielen, P.W. Microbial Growth in Drinking-Water Supplies; Iwa Publishing: London, UK, 2014.

75. Eilers, K.G.; Lauber, C.L.; Knight, R.; Fierer, N. Shifts in Bacterial Community Structure Associated with Inputs of Low Molecular Weight Carbon Compounds to Soil. Soil Biol. Biochem. 2010, 42, 896-903. [CrossRef]

76. Reintjes, G.; Arnosti, C.; Fuchs, B.; Amann, R. Selfish, Sharing and Scavenging Bacteria in the Atlantic Ocean: A Biogeographical Study of Bacterial Substrate Utilisation. ISME J. 2019, 13, 1119-1132. [CrossRef]

77. Freilich, S.; Zarecki, R.; Eilam, O.; Segal, E.S.; Henry, C.S.; Kupiec, M.; Gophna, U.; Sharan, R.; Ruppin, E. Competitive and Cooperative Metabolic Interactions in Bacterial Communities. Nat. Commun. 2011, 2. [CrossRef]

78. Benölken, J.; Dorsch, T.; Wichmann, K.; Bendinger, B. Praxisnahe Untersuchungen Zur Kontamination von Trinkwasser in Halbtechnischen Trinkwasser-Installationen. In IWW Schriftenreihe_Vermeidung und Sanierung von Trinkwasserkontaminationen Durch Hygienisch Relevante Mikroorganismen aus Biofilmen der Hausinstallation; IWW Schriftenreihe: Mülheim, Germany, 2010; pp. 101-180.

79. Nemergut, D.R.; Schmidt, S.K.; Fukami, T.; Neill, S.P.O.; Bilinski, T.M.; Stanish, L.F.; Knelman, J.E.; Darcy, J.L.; Lynch, R.C.; Wickey, P. Patterns and Processes of Microbial Community Assembly. Microbiol. Mol. Biol. Rev. 2013, 77, 342-356. [CrossRef]

80. Vellend, M. Conceptual Synthesis in Community Ecology. Q. Rev. Biol. 2010, 85, 183-206. [CrossRef] 
81. Van der Kooij, D. Assimilable Organic Carbon as an Indicator of Bacterial Regrowth. J. Am. Water Work. Assoc. 1992, 84, 57-65. [CrossRef]

82. Stadt Zurich, W. The Quality of Zurich's Drinking Water. 1-2. Available online: https://www.stadtzuerich.ch/dib/de/index/wasserversorgung/Qualitaetsueberwachung/qualitaetswerte.html (accessed on 31 October 2019).

83. Boks, N.P.; Busscher, H.J.; van der Mei, H.C.; Norde, W. Bond-Strengthening in Staphylococcal Adhesion to Hydrophilic and Hydrophobic Surfaces Using Atomic Force Microscopy. Langmuir 2008, 24, 12990-12994. [CrossRef] [PubMed]

84. Schwab, U.; Hu, Y.; Wiedmann, M.; Boor, K.J. Alternative Sigma Factor $\sigma B$ Is Not Essential for Listeria Monocytogenes Surface Attachment. J. Food Prot. 2005, 68, 311-317. [CrossRef] [PubMed]

85. Van Der Kooij, D.; Visser, A.; Hijnen, W.A.M. Determing the Concentration of Easily Assimilable Organic Carbon in Drinking. Am. Water Work. Assoc. 1982. [CrossRef]

86. Hammes, F.A.; Egli, T. New Method for Assimilable Organic Carbon Determination Using Flow-Cytometric Enumeration and a Natural Microbial Consortium as Inoculum. Environ. Sci. Technol. 2005, 39, 3289-3294. [CrossRef] [PubMed]

87. Waines, P.L.; Moate, R.; Moody, A.J.; Allen, M.; Bradley, G. The Effect of Material Choice on Biofilm Formation in a Model Warm Water Distribution System. Biofouling 2011, 27, 1161-1174. [CrossRef] [PubMed]

88. Whelton, A.J.; Cooney, M.F. We Need Our Customers to Complain. Opflow 2004, 30, 1-7. [CrossRef]

89. Shah, P.; Barskey, A.; Binder, A.; Edens, C.; Lee, S.; Smith, J.; Schrag, S.; Whitney, C.; Cooley, L. Legionnaires' Disease Surveillance Summary Report, United States. Available online: https:/www.cdc.gov/legionella/ health-depts/surv-reporting/2016-17-surv-report-508.pdf (accessed on 31 October 2019).

90. Bundesamt für Gesundheit BAG. Zahlen Zu Infektionskrankheiten: Legionellose; Bundesamt für Gesundheit BAG: Bern, Switzerland, 2019.

91. Richards, A.M.; Von Dwingelo, J.E.; Price, C.T.; Kwaik, Y.A. Cellular Microbiology and Molecular Ecology of Legionella-Amoeba Interaction. Virulence 2013, 4, 307-314. [CrossRef]

92. Falkinham, J.; Pruden, A.; Edwards, M. Opportunistic Premise Plumbing Pathogens: Increasingly Important Pathogens in Drinking Water. Pathogens 2015, 4, 373-386. [CrossRef]

93. Völker, S.; Schreiber, C.; Kistemann, T. Drinking Water Quality in Household Supply Infrastructure-A Survey of the Current Situation in Germany. Int. J. Hyg. Environ. Health 2010, 213, 204-209. [CrossRef] [PubMed]

94. Bédard, E.; Prévost, M.; Déziel, E. Pseudomonas Aeruginosa in Premise Plumbing of Large Buildings. Microbiologyopen 2016, 5, 937-956. [CrossRef] [PubMed]

95. Feazel, L.M.; Baumgartner, L.K.; Peterson, K.L.; Frank, D.N.; Harris, J.K.; Pace, N.R. Opportunistic Pathogens Enriched in Showerhead Biofilms. PNAS 2009, 106, 16393-16399. [CrossRef] [PubMed]

96. Falkinham, J.O. Reducing Human Exposure to Mycobacterium avium. Ann. Am. Thorac. Soc. 2013, 10, 378-382. [CrossRef]

97. Gebert, M.J.; Delgado-Baquerizo, M.; Oliverio, A.M.; Webster, T.M.; Nichols, L.M.; Honda, J.R.; Chan, E.D.; Adjemian, J.; Dunn, R.R.; Fierer, N. Ecological Analyses of Mycobacteria in Showerhead Biofilms and Their Relevance to Human Health. MBio 2018, 9, e01614-18. [CrossRef]

98. Vital, M.; Stucki, D.; Egli, T.; Hammes, F. Evaluating the Growth Potential of Pathogenic Bacteria in Water. Appl. Environ. Microbiol. 2010, 76, 6477-6484. [CrossRef]

99. Stüken, A.; Haverkamp, T.H.A.; Dirven, H.A.A.M.; Gilfillan, G.D.; Leithaug, M.; Lund, V. Microbial Community Composition of Tap Water and Biofilms Treated with or without Copper-Silver Ionization. Environ. Sci. Technol. 2018, 52, 3354-3364. [CrossRef]

100. Golberg, K.; Emuna, N.; Vinod, T.P.; Van Moppes, D.; Marks, R.S.; Arad, S.M.; Kushmaro, A. Novel Anti-Adhesive Biomaterial Patches: Preventing Biofi Lm with Metal Complex Films (MCF) Derived from a Microalgal Polysaccharide. Adv. Mater. Interfaces 2016, 1500486. [CrossRef]

(C) 2020 by the authors. Licensee MDPI, Basel, Switzerland. This article is an open access article distributed under the terms and conditions of the Creative Commons Attribution (CC BY) license (http://creativecommons.org/licenses/by/4.0/). 